\title{
Recent genetic changes in enhanced populations of sea trout (Salmo trutta m. trutta) in the southern Baltic rivers revealed with SNP analysis
}

\author{
Roman Wenne ${ }^{1, a}$, Rafał BernAS ${ }^{2}$, Anita PoćWIERZ-Kotus $^{1}$, Agata DrYWA $^{3}$ and Anna WAुS ${ }^{3}$ \\ ${ }^{1}$ Institute of Oceanology, Polish Academy of Sciences, Powstańców Warszawy 55, 81712 Sopot, Poland \\ 2 Inland Fisheries Institute in Olsztyn, Department of Migratory Fishes in Rutki, 83-330 Żukowo, Poland \\ 3 National Marine Fisheries Research Institute, Kołłataja 1, 81332 Gdynia, Poland
}

Received 7 December 2015; Accepted 31 March 2016

\begin{abstract}
The genetic structure of a fish population is usually thought to be stable over time. In the southern Baltic, Salmo trutta m. trutta (sea trout) populations have been characterized by low degree of genetic differentiation. All studied populations had been heavily stocked with mixed material for many years prior to the sampling period, including releases of Pomeranian sea trout to the Vistula River in Poland, Southern Baltic. However, the strategy of stocking became river based a few years before the sampling began. Juveniles from artificial reproduction are released only to their parental river, which reduces the mixing of the gene pool of fish from different populations. Changes in sea trout populations in the southern Baltic over time were studied using single nucleotide polymorphisms (SNPs). Genetic composition of populations of sea trout in the Vistula and Drwęca river system were found to increasingly resemble the non-admixed hatchery population from Aquamar (Miastko, Poland), whereas the Pomeranian populations were stable. The implementation of a new stocking strategy for the restoration and protection of Vistula sea trout was noted as possible explanation. With the increase of natural breeding, artificial enhancement of sea trout populations should be reduced.
\end{abstract}

Keywords: Population genetics / management of populations / brown trout / homing / population structure / changes over time

\section{Introduction}

The supplementing of diminishing endangered natural populations or restitution of extinct populations with reared specimens has been a common practice applied as a countermeasure to deterioration of living resources and the environment (Araki and Schmid 2010; Laikre et al. 2010). The enhancements have often been reported to have had negative effects on natural populations of fish (Ward 2006). These enhancements have included releases of artificially reared stocks or escapes of large numbers of individuals characterized by lower fitness (Satake and Araki 2011; Baskett et al. 2013; Milot et al. 2013; Naish et al. 2013) and lower genetic diversity have been reported for some species, including Adriatic sturgeon (Boscari and Congiu 2014), Korean starry flounder (An et al. 2013) and black sea bream in Japan (Blanco Gonzalez and Umino 2009). Other effects have been introductions of nonindigenous populations, such as salmon in Poland (Poćwierz-Kotus et al. 2015a; Bernaś et al. 2016); or alien populations of the same species and their subsequent hybridization

\footnotetext{
${ }^{a}$ Corresponding author: rwenne@iopan.gda.pl
}

with local native populations, as with salmon and brown trout in Bulgaria (Chelenkova et al. 2012), Norway (Thaulow et al. 2012), Hungary (Horváth et al. 2013) and in Spain (Madeira et al. 2005), pikeperch in Finland (Salminen et al. 2012); unintentional escapes from hatcheries as red sea bream in Japan (Blanco Gonzalez et al. 2015), salmon in Norway (Liu et al. 2013) and Canada (Fraser et al. 2008). Accidental or deliberate introductions of exotic and invasive species to new environments, often beneficial economically, causes distortions in the functioning of local ecosystems and can threaten native populations of fish and shellfish, as in the case of brown trout in Japan (Hasegawa and Maekawa 2008), Patagonia (Vigilano et al. 2007; Young et al. 2010) and in North America (Turek et al. 2016), mussel Mytilus in Europe and South Africa (Kijewski et al. 2009; McQuaid et al. 2015 and oyster Crassostrea gigas (Carlton 1979; Meehan et al. 1989; Miller et al. 2012; Lallias et al. 2015). Stocking and introductions to marine farms can also be the means of spreading diseases, as in salmon in Chile (Murray 2013; Marshall et al. 2014) and oyster Crassostrea gigas in Europe (Mineur et al. 2014). The application of genetic research facilitated more effective stocking e.g. as in sea bass in the USA (Darden et al. 2013) and a reduction of 
their negative effects in white seabass populations (Gruenthal and Drawbridge 2012) and bay scallop (Bert et al. 2011).

In the last decades, a range of new molecular genetic techniques have been used to study fish and shellfish evolution, and changes in wild populations including those associated with exploitation, stocking and research related to aquaculture (e.g. Utter et al. 1987; Wenne 1992; Poteaux and Berrebi 1997; Halvorson et al. 2001; Wạs et al. 2004; Poćwierz-Kotus et al. 2007; Wenne et al. 2007; Filipowicz et al. 2008; Beaumont et al. 2010; Poćwierz-Kotus and Wenne 2010; Poćwierz-Kotus et al. 2010; Wenne et al. 2011; Kohout et al. 2013; Nakajima et al. 2014). Microsatellites are regularly used in fisheries related applications and research (Wa̧s and Wenne 1998; Griffiths et al. 2013; Perrier et al. 2013; Pukk et al. 2013; Bernaś et al. 2014; Koljonen et al. 2014; Thaulow et al. 2014; Valiquette et al. 2014). However, the high potential of more recently discovered and developed single nucleotide polymorphisms (SNPs) to uncover population structures and find genomic regions (islands) under selection has become increasingly recognized (Lamaze et al. 2012; Pustovrh et al. 2012; Ozerov et al. 2013; Milano et al., 2014; Poćwierz-Kotus et al. 2015b; Sušnik Bajec et al. 2015). SNPs are biallelic markers characterized by codominant inheritance, lack of homoplasy and an infinite model of mutation (Morin et al. 2004; Beacham et al. 2010; Seeb et al. 2011) Analyzing the drawbacks of use SNPs the most important are lower discrimination power in comparison with microsatellites, non-neutrality, possibility of random genetic drift and ascertainment bias. Glover et al. (2010) demonstrated that identification of highly informative SNP markers from the screening of larger pools represents a powerful technique to create molecular tools, both to study individual membership of populations and for population differentiation.

Brown trout (Salmo trutta L.) is a palearctic salmonid species, which is naturally distributed in Europe and adjacent waters (Klemetsen et al. 2003). It was introduced to, and subsequently colonized drainages, lakes and coastal waters in North (Canada and USA) and South America (Chile and Argentina), Kerguelen, New Zealand, southern Australia and Japan. The anadromous form of brown trout, sea trout (S. t. trutta) usually spawn in freshwater streams and rivers with juveniles generally staying 1-3 years in the natal rivers before smoltification from the parr stadium and migration to the sea. A decline in natural reproduction resulted in a significant reduction in the number of smolts descending to the sea which, in turn, justified development of massive stocking in Europe and most Baltic countries since many years including Poland (Bartel 1993). On average between the years 2002-2012, 34 mln smolts were released in Baltic countries, including $9.5 \mathrm{mln}$ in Poland (ICES 2013). Many more alevins and fry were released; $7 \mathrm{mln}$ in Poland in 2012 alone.

In Poland there are about 25 rivers, in which sea trout occur (Pedersen et al. 2012). Building dams without appropriate passages prevented sea trout migration and spawning up the rivers. Regular stocking of the Vistula and Pomerania rivers has been conducted since the 1960s. But this was carried out without regard to the origin of the sea trout stocked. Therefore, populations were mixed before the 1990s. Mixed stocking may have started in the nineteenth century but

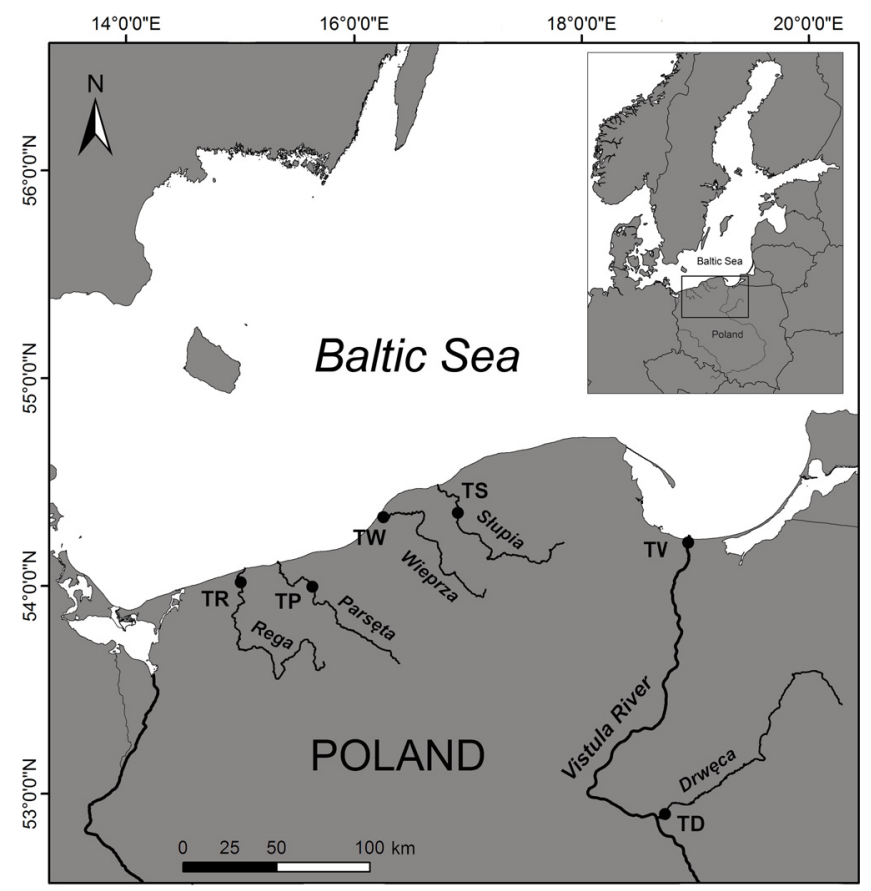

Fig. 1. Sea trout sampling locations: TV - Vistula River; TD -Drwęca River; TR - Rega River; TP - Parsęta River; TS - Słupia River; TW - Wieprza River, TM - the hatchery in Miastko.

political upheavals over the period make a precise tracking of the stocking process difficult. All populations in rivers are considered as mixed after approximately 120 years of occasional, and more than 50 years of intensive stocking. According to the HELCOM (2011) report, the status of the sea trout populations from the Vistula River was presented as 'reared' (no, or almost no, natural reproduction) with migratory hindrances. Of the populations from Pomeranian rivers: Parsęta and Słupia (Fig. 1) were qualified as mixed, with natural reproduction and with large-scale fish releases; whereas Rega and Wieprza rivers showed lower (below $10 \%$ of smolts) natural reproduction. In the case of the Drwęca River, a tributary of the Vistula, the level of wild smolts was much lower than in Pomeranian rivers (HELCOM 2011).

In the past, the Vistula sea trout had the largest catchments compared to other river populations in the Baltic Sea drainage (Bartel 1988) and consisted of two stocks: winter and summer. The main part of the population used to be the winter stock (Żarnecki 1963). Th decline in the sea trout Vistula population, compared to the 1950s and 60s, was caused by the construction of a dam in Włocławek in 1968 (Bartel 1993). The low number of eggs obtained from Vistula specimens resulted in the translocation of stocking material in the 1970s from Pomeranian sea trout, originating from the Parsęta - Słupia rivers area, to the Vistula River. This translocation caused the decay of original Vistula sea trout characteristics (Borzȩcka 2010).

Several million sea trout at early stages of development (alevins, fry, and parr) and smolts have been released annually into the Vistula River and its tributaries. For smolts released to the Vistula River and its tributaries, homing was very high and ranged from 94\% to 99.3\% (Dębowski and Bartel 1995). However, smolts released into Pomeranian rivers estuaries had 
Table 1. The location and time of sampling.

\begin{tabular}{|c|c|c|c|c|c|c|c|}
\hline No & Sample & Name & Localization & & Sampling time & Fish no. & Population \\
\hline 1 & Vistula River & TV 96 & Świbno & \multirow[t]{6}{*}{1996} & September & 40 & Vistula (wild) \\
\hline 2 & Drwȩca River & TD 96 & Lubicz & & November & 42 & Vistula (wild) \\
\hline 3 & Rega River & TR 96 & Trzebiatów & & November & 42 & Pomeranian (wild) \\
\hline 4 & Parsęta River & TP 96 & Karlino & & December & 40 & Pomeranian (wild) \\
\hline 5 & Słupia River & TS 96 & Słupsk & & October & 41 & Pomeranian (wild) \\
\hline 6 & Wieprza River & TW 96 & Darłowo & & October & 42 & Pomeranian (wild) \\
\hline 1 & Vistula River & TV 09 & Świbno & \multirow[t]{6}{*}{2009} & October & 50 & Vistula (wild) \\
\hline 2 & Drwȩca River & TD 09 & Lubicz & & September- November & 49 & Vistula (wild) \\
\hline 3 & Rega River & TR 09 & Trzebiatów & & September- November & 50 & Pomeranian (wild) \\
\hline 4 & Parsęta River & TP 09 & Białogard & & September- November & 50 & Pomeranian (wild) \\
\hline 5 & Słupia River & TS 09 & Słupsk & & November & 50 & Pomeranian (wild) \\
\hline 6 & Wieprza River & TW 09 & Darłowo & & September- November & 50 & Pomeranian (wild) \\
\hline \multirow[t]{2}{*}{7} & Miastko Hatchery & TM 05 & Miastko hatchery & 2005 & November & 50 & $\begin{array}{l}\text { Vistula (hatchery originally } \\
\text { from Świbno) }\end{array}$ \\
\hline & & & & & Total & 595 & \\
\hline
\end{tabular}

a significantly lower percentage of homing. The stocking of the Pomeranian rivers comprises $30-40 \%$ of the total of Polish sea trout releases (Pedersen et al. 2012). The 'Stocking of Polish marine areas' programme of The Ministry of Agricultural and Rural Development Board currently regulates both stocking and the duties of particular fishing region users. Juveniles from artificial reproduction are released only to their parental river, which restricts the mixing of the gene pool of fish from different populations as happened in the past, before 1990s. In addition, the passages in Poland have been improved since and this may also have contributed to the enhanced restitution of natural spawning.

Studies carried out in the middle of 1990s using allozyme markers, shortly after implementation of the more restrictive stocking strategy indicated that the genetic structure of populations from the Pomeranian rivers Rega and Parsęta, as well as from the Słupia and Vistula rivers was disturbed (Woźnicki et al. 1999; Łuczyński et al. 2000; Wenne et al. 2000). A low level of differentiation between Vistula River and łupia River populationshas been demonstrated using mtDNA (Włodarczyk and Wenne 2001), and growth hormone gene 2 (GH2) marker analysis (Włodarczyk et al. 1999). A slightly higher level of differentiation was observed by the application of microsatellite DNA (Wass and Wenne 2002; 2003). However, no molecular markers have been found suitable for application in tracing the origin of spawners entering the Vistula river. Newer studies based on SNP methodology enabled the differentiation of the Vistula and Pomeranian (Słupia) sea trout populations (Drywa et al. 2013).

The aim of this paper was to find changes over 13 years in genetic structure of very weakly spatially differentiated and intensively enhanced sea trout populations in southern Baltic, Poland.

\section{Material and methods}

\subsection{Sample collection and DNA extraction}

Two sets of sea trout samples collected from 6 rives in 1996 and 2009 were studied. Approximately 5 mm$^{2}$ fin clip samples were collected from 595 individuals. Adult spawners were caught in traps in 5 rivers and electrofished in Parsęta River in 1996 and 2009, and adult spawners from the Aquamar hatchery in Miastko, Poland in 2005 used for artificial spawning (Fig. 1, Table 1). The hatchery stock in Aquamar is thought to represent a native winter migrating group of sea trout in the Vistula River and is used for production of stocking material for releases in the Vistula only. Fin clips were stored in $95 \% \mathrm{EtOH}$ solution at $4{ }^{\circ} \mathrm{C}$ prior to DNA extraction. Genomic DNA was extracted using Genomic Mini Kit (A\&A Biotechnology). DNA quality was assessed by running sample aliquots on $1 \%$ agarose gels. Samples were quantified using the Epoch ${ }^{\mathrm{TM}}$ Spectrophotometer System (BioTek) and diluted to a final concentration of $20 \mathrm{ng} / \mu \mathrm{l}$ in TE buffer.

\subsection{SNP genotyping and evaluation of genetic differences between populations}

Assays were designed for 62 candidate SNPs selected from results of genotyping with the Atlantic salmon custom design Illumina iSelect SNP array containing 15225 markers of 24 samples of sea trout from Vistula and Slupia rivers (Drywa et al. 2013; 2014; Poćwierz-Kotus et al. 2014). SNP genotyping was performed using the Sequenom MassARRAY iPLEX platform (Gabriel et al. 2009) in Centre for Integrative Genetics, Department of Animal and Aquacultural Sciences, Norwegian University of Life Sciences, Ås, Norway. Polymorphic loci in the studied sea trout populations were selected from genotyping results using locus-by-locus AMOVA (Analysis of Molecular Variance) after 10000 permutations. Population genetic differentiation was analyzed using global weighted average $F$-statistic over loci and pairwise $F_{\text {ST }}$ (Weir and Cockerham 1984; Weir 1996) with 1000 permutations and significance level $P<0.05$. The critical probability value for each test was adjusted using the Bonferroni correction (Rice 1989) using FSTAT software 2.9.3.2 (Goudet 1995). Genetic diversity was assessed by number of polymorphic SNPs $\left(P_{O}\right)$ and values of observed $\left(H_{O}\right)$ and expected $\left(H_{E}\right)$ heterozygosity (Nei 1978; 1987). All tests, except Bonferroni correction, were carried out by Arlequin 3.5.1.2 (Excoffier and Lischer 2010). 
Takezaki's POPTREE program was used to create a neighbor joining tree using $D_{A}$ distances (Nei 1978) with 1000 bootstrap replications (Takezaki et al. 2010). The identification of distinct genetic populations and individuals assignment to them was performed with a Bayesian-model-based, clustering analysis using Structure 2.3.4 (Pritchard et al. 2000). Individuals were assigned to predefined $K$ populations (from $K=1-$ 16 with 10 iterations for each $K$ ), where each $K$ was characterized by a set of allele frequencies for each locus. An admixture model with no a priori information on the origin of the individuals with 10000 repetitions as burn in, and 100000 repetitions after burn in, was applied. Individuals were probabilistically assigned to one or more clusters if their genotypes indicated a mixing. The true $K$ was estimated following the method described by Evanno et al. (2005) using STRUCTURE HARVESTER program (Earl and vonHoldt 2012). The CLUMPP 1.1.2 (Jakobsson and Rosenberg 2007) software was used to average the results from the ten replicate cluster analyses. Full Search algorithm and 10000 random permutations were applied.

Correspondence between populations was assessed using a three-dimensional Factorial Correspondence Analysis (FCA) implemented in GENETIX 4.05.2 software (Belkhir et al. 2000; Benzécri 1992). The ability of the selected markers set to assign individuals to the most likely population, indicated by STRUCTURE 2.3.4 software, was assessed using ONCOR software (Kalinowski et al. 2007). Assignment tests to evaluate the accuracy of identification of individuals to populations by leave-one-out method were performed. Two approaches were applied. First, with a priori baseline populations and second with reporting groups based on clustering results.

\section{Results}

\subsection{Characterization of SNPs, quality control and basic statistics}

A total of 595 sea trout specimens from 6 rivers and a hatchery in Poland were genotyped. Candidate SNPs were divided into three groups: failed (lack of genotyping results), monomorphic and polymorphic. Missing data rate, set at a 5\% level, reduced the number of specimens to 576 and loci to 47 , of which 14 loci were monomorphic and another 4 had minor allele frequency (MAF) values lower than 0.01. The remaining 29 loci were used for further analysis. AMOVA analysis resulted in the selection of 22 polymorphic loci $\left(P_{O}\right)$ with statistically significant results in all populations. Table 2 shows frequencies of alleles for the 13 studied sea trout populations.

The most common polymorphism was $\mathrm{A} / \mathrm{G}$ appearing in 12 loci (Table 3 ). The global $F_{\mathrm{ST}}$ was 0.03 . The highest $F_{\mathrm{ST}}$ value for individual loci obtained in AMOVA was 0.095 for locus no. 14 and the lowest was 0.007 for locus No. 21. The highest heterozygosity values were observed for 6 loci with values around 0.5 . And the lowest heterozygosity values were present in 3 loci with values less than 0.1 (Table 3). Most of the loci were in Hardy-Weinberg equilibrium (HWE). The highest numbers of loci in $\mathrm{H}-\mathrm{W}$ disequilibrium were found in the hatchery population TM 05 (Table 4). This may have been an unfavorable effect occurring in breeding: founder effect, nonrandom mating and limited gene pool, or it may have been a high number of closely related individuals in the sample analyzed (Wa̧s and Bernaś 2016). SNPs were polymorphic $\left(P_{O}\right)$ in different numbers for particular populations, from 18 for TR 96 population to 22 for 4 populations; TV 96, TD 96, TW 96 and TS 09. The percentage of polymorphic SNPs ranged from $82 \%$ to $100 \%$ in populations. Average gene diversity over loci in populations ranged from 0.170 for TM 05 to 0.270 for TW 09 (Table 4). A significant excess of homozygotes was noticed in 3 populations, mainly in those collected in 1996 (TV 96, TR 96) and in the population TD 09 (with the largest excess).

\subsection{Genetic differences between populations}

Genetic differences between pairs of populations ranged from 0 to 0.16 (Table 5). Forty seven $(47.44 \%)$ of the $F_{\text {ST }}$ values greater than 0 were statistically significant $(P<0.05)$. The samples collected from rivers in 2009 showed greater differentiation than those from 1996. Vistula samples from 2009 (TV 09 and TD 09), when compared to samples from the Pomeranian rivers from 2009 showed greater differentiation than shown by a similar comparison of the same sampling sites from 1996. After Bonferroni correction $8(10 \%)$ of the $F_{\text {ST }}$ values were statistically significant $(P<0.00064)$. Among the other pairs of populations statistically significant differentiation was found for the Vistula and Wieprza populations from 2009. The hatchery population (TM 05) was the most divergent and differentiated from all other samples, but less divergent from Vistula (TV 09) and Drwęca (TD 09) samples. Neighbor-joining (NJ) trees constructed on the basis of the $D_{A}$ distances from 22 loci showed genetic relationships between the analyzed populations. In samples from the 1996 differentiation between Vistula River and Pomeranian rivers was not observed. Even more, the TV 96 group was clustered with TS 96 and TP 96 (Fig. 2a). 13 years later Vistula sea trout populations (including Drwęca River) were significantly different from Pomeranian populations. The analysis of 7 populations demonstrated similarity between Vistula (TV 09) and its tributary Drwęca (TD 09) and a hatchery sample TM 05 (Fig. 2b).

STRUCTURE analysis was carried out for 22 selected loci. The highest value of delta $\mathrm{K}$ was estimated for $K=3$ and reached 1900.56 without other significant peaks (Figs. 3a and $3 b$ ). A Factorial Correspondence Analysis (FCA) was carried out to investigate genetic relationships among the 12 samples from rivers (Fig. 4). The first two axes accounted for $69 \%$ of the total variation. The first axis ( $42.42 \%$ variance) showed separation between all Pomeranian samples from 1996 and 2009 and Vistula River samples from 1996, and the Vistula trout samples from 2009: TD 09 and TV 09. In addition, all samples from 1996 formed a very homogenous group while Pomeranian samples from 2009 were more spread. The leaveone-out test, in ONCOR, found $17.7 \%$ of fish correctly assigned back to the river from which they were sampled. After the formation of two main reporting groups, by structure analysis results, the proportion of correctly self-assigned individuals increased to $82 \%$. In the first group consisting of all samples apart from hatchery TM 05, self-assignment accounted for $85 \%$. In the second, hatchery TM 05 , self-assignment was $78 \%$. 


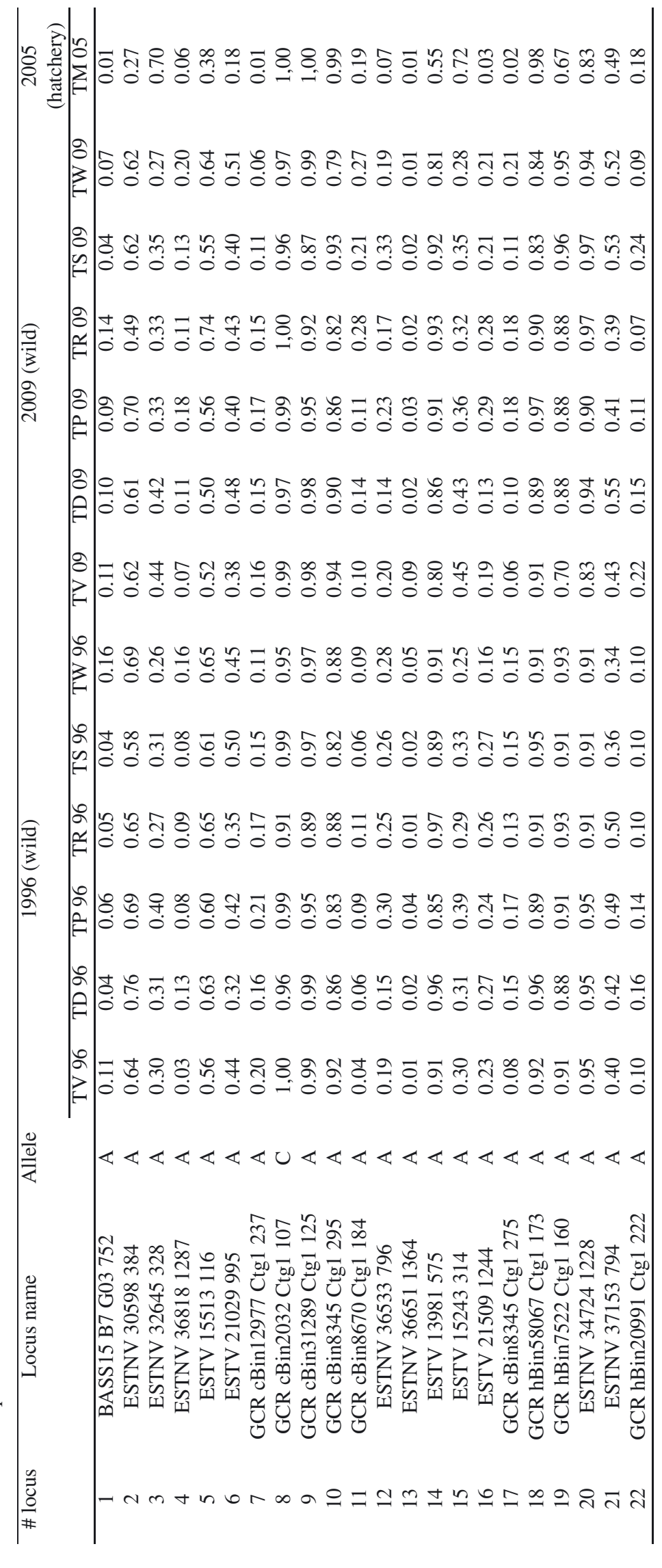


Table 3. Genetic variability of 22 SNPs in 13 sea trout populations. MAF = Minor Allele Frequency; rs = reference SNP ID from dbSNP; $\mathrm{H}_{\mathrm{O}}$ - observed heterozygosity; $\mathrm{H}_{\mathrm{E}}$ - expected heterozygosity. Loci marked with an asterisk have a highly significant deviations $(P<0.01)$ from Hardy-Weinberg equilibrium.

\begin{tabular}{ccccccccc}
\hline Locus\# & Locus name & Region & Allele & $F_{\text {ST }}$ & Mean MAF & dbSNP access & Averange Ho & Averange He \\
\hline 1 & BASS15 B7 G03 752 & Coding & A/C & 0.014 & 0.078 & rs119097369 & 0.128 & 0.143 \\
2 & ESTNV 30598 384 & Coding & A/G & 0.052 & 0.391 & rs159406625 & 0.460 & 0.453 \\
3 & ESTNV 32645 328 & Coding & A/G & 0.041 & 0.358 & rs159404820 & 0.350 & $0.442^{*}$ \\
4 & ESTNV 36818 1287 & Coding & A/G & 0.012 & 0.110 & & 0.190 & $0.191^{*}$ \\
5 & ESTV 15513 116 & Coding & A/G & 0.022 & 0.420 & & 0.538 & 0.477 \\
6 & ESTV 21029 995 & Coding & A/G & 0.022 & 0.406 & & 0.501 & $0.474^{*}$ \\
7 & GCR cBin12977 Ctg1 237 & Coding & A/T & 0.014 & 0.136 & rs159401279 & 0.237 & 0.236 \\
8 & GCR cBin2032 Ctg1 107 & Coding & C/G & 0.014 & 0.024 & rs159401555 & 0.066 & 0.049 \\
9 & GCR cBin31289 Ctg1 125 & Coding & A/G & 0.027 & 0.042 & & 0.092 & 0.079 \\
10 & GCR cBin8345 Ctg1 295 & Coding & A/T & 0.020 & 0.123 & & 0.198 & 0.214 \\
11 & GCR cBin8670 Ctg1 184 & Coding & A/C & 0.041 & 0.144 & rs159403953 & 0.209 & 0.226 \\
12 & ESTNV 36533 796 & Coding & A/G & 0.023 & 0.209 & & 0.325 & 0.329 \\
13 & ESTNV 36651 1364 & Coding & A/G & 0.008 & 0.029 & rs159405523 & 0.057 & 0.055 \\
14 & ESTV 13981 575 & Coding & A/C & 0.095 & 0.140 & rs119097008 & 0.208 & 0.211 \\
15 & ESTV 15243 314 & Coding & A/G & 0.041 & 0.362 & rs119097514 & 0.370 & 0.444 \\
16 & ESTV 21509 1244 & Coding & A/G & 0.022 & 0.209 & & 0.425 & $0.329^{*}$ \\
17 & GCR cBin8345 Ctg1 275 & Coding & A/T & 0.016 & 0.129 & & 0.216 & 0.224 \\
18 & GCR hBin58067 Ctg1 173 & Coding & A/G & 0.017 & 0.088 & & 0.164 & 0.157 \\
19 & GCR hBin7522 Ctg1 160 & Coding & A/C & 0.062 & 0.129 & rs159402846 & 0.216 & 0.208 \\
20 & ESTNV 34724 1228 & Coding & A/T & 0.018 & 0.082 & rs159405162 & 0.161 & 0.146 \\
21 & ESTNV 37153 794 & Coding & A/G & 0.007 & 0.453 & rs159407311 & 0.550 & 0.492 \\
22 & GCR hBin20991 Ctg1 222 & Coding & A/C & 0.011 & 0.138 & rs159403997 & 0.246 & 0.233 \\
\hline
\end{tabular}

Table 4. Genetic variability of 13 sea trout populations among 22 SNPs. $\mathrm{H}_{\mathrm{O}}$ - observed heterozygosity; $\mathrm{H}_{\mathrm{E}}-$ expected heterozygosity; $\mathrm{P}_{\mathrm{O}}-$ polymorphic loci; Loci no. with highly significant HWE departure $(P<0.01)$ in populations are listed in parentheses. $F_{\text {IS }}-$ the inbreeding coefficient (values with $P<0.05$ are marked in bold).

\begin{tabular}{cccccccc}
\hline Pop & Mean Ho & Mean He & No. of Po & $\begin{array}{c}\text { Average gene diversity } \\
\text { over loci }\end{array}$ & $\begin{array}{c}\text { Number of loci with HWE } \\
\text { departure }(P<0.05)\end{array}$ & Specimens no. & $F_{\text {IS }}$ \\
\hline TV 96 & 0.222 & 0.252 & 22 & 0.211 & 3 (no. 3) & 38 & $\mathbf{0 . 0 8 2}$ \\
TD 96 & 0.237 & 0.244 & 22 & 0.213 & 2 & 41 & 0.037 \\
TP 96 & 0.272 & 0.281 & 21 & 0.251 & 0 & 39 & 0.022 \\
TR 96 & 0.243 & 0.262 & 18 & 0.225 & 0 & 34 & $\mathbf{0 . 0 5 5}$ \\
TS 96 & 0.267 & 0.259 & 21 & 0.218 & 1 & 41 & -0.030 \\
TW 96 & 0.271 & 0.262 & 22 & 0.226 & 0 & 40 & -0.027 \\
TV 09 & 0.288 & 0.29 & 19 & 0.227 & 0 & 49 & 0.001 \\
TD 09 & 0.251 & 0.268 & 20 & 0.225 & 1 & 49 & $\mathbf{0 . 0 3 8}$ \\
TP 09 & 0.323 & 0.276 & 19 & 0.217 & 3 (no. 16) & 49 & -0.117 \\
TR 09 & 0.307 & 0.288 & 19 & 0.247 & 1 & 48 & -0.041 \\
TS 09 & 0.264 & 0.279 & 22 & 0.257 & 2 (no. 6) & 48 & 0.035 \\
TW 09 & 0.332 & 0.279 & 20 & 0.270 & 5 (no.4) & 50 & -0.124 \\
TM 05 & 0.246 & 0.242 & 19 & 0.170 & & 50 \\
\hline
\end{tabular}

\section{Discussion}

The negative effect of dams on populations of freshwater and anadromous fish as manifested by blocking spawning and foraging migrations, population fragmentation or changed water regimes have been reported often (e.g. Jager et al. 2001; Morita and Yamamoto 2002). All of them have genetic consequences, for example reduction in effective population size, shift in migration-selection-drift equilibrium and in local adaptations (Meldgaard et al. 2003; Faulks et al. 2011; Paris et al. 2015). A divergence of brown trout populations isolated by dams established as early as middle ages has been found (Hansen et al. 2014).
Considerable temporal stability of genetic composition of brown trout populations have previously been demonstrated (Hansen et al. 2002; Jensen et al. 2005). Studies, based on microsatellite DNA, in some cases resulted in the observation of temporal changes in the genetic composition, which may be explained by drift in small persisting populations of brown trout (Ostergaard et al. 2003). However, in larger populations of salmon, temporal variation in allele frequencies was due to the effect of hatchery practices (Koljonen et al. 2005). Hansen et al. (2009) have shown admixture of brown trout populations in Denmark with hatchery trout. The admixture may have caused reduced local adaptation. However, in contrast to Danish populations, Polish populations have been very 
Table 5. $F_{\text {ST }}$ pairwise differences for 22 SNPs. Bolded values are statistically significant. Values with an asterisk are statistically significant after Bonferroni correction.

\begin{tabular}{|c|c|c|c|c|c|c|c|c|c|c|c|c|}
\hline & TV 96 & TD 96 & TP 96 & TR 96 & TS 96 & TW 96 & TV 09 & TD 09 & TP 09 & TR 09 & TS 09 & TW 09 \\
\hline TD 96 & 0.003 & & & & & & & & & & & \\
\hline ТР 96 & 0.000 & 0.003 & & & & & & & & & & \\
\hline TR 96 & 0.005 & -0.009 & -0.009 & & & & & & & & & \\
\hline TS 96 & -0.005 & 0.008 & -0.005 & -0.07 & & & & & & & & \\
\hline TW 96 & -0.002 & 0.007 & 0.004 & -0.006 & -0.001 & & & & & & & \\
\hline TV 09 & 0.014 & 0.026 & 0.008 & 0.017 & 0.019 & 0.030 & & & & & & \\
\hline TD 09 & 0.000 & 0.015 & 0.000 & 0.006 & 0.006 & 0.016 & 0.002 & & & & & \\
\hline ТP 09 & -0.002 & -0.005 & -0.011 & -0.010 & -0.008 & -0.006 & 0.009 & 0.006 & & & & \\
\hline TR 09 & 0.009 & 0.014 & 0.007 & 0.004 & -0.003 & 0.000 & 0.017 & 0.016 & 0.010 & & & \\
\hline TS 09 & 0.010 & 0.011 & 0.000 & -0.008 & 0.004 & 0.009 & 0.011 & 0.007 & 0.007 & 0.017 & & \\
\hline TW 09 & 0.014 & 0.019 & 0.004 & 0.004 & 0.003 & 0.004 & $0.029 *$ & 0.012 & 0.004 & 0.002 & 0.013 & \\
\hline TM 05 & 0.133 & $0.150 *$ & 0.118* & 0.148 & $0.134 *$ & $0.155^{*}$ & 0.065 & 0.081 & $0.130 *$ & 0.121 & 0.108 & $0.128 *$ \\
\hline
\end{tabular}

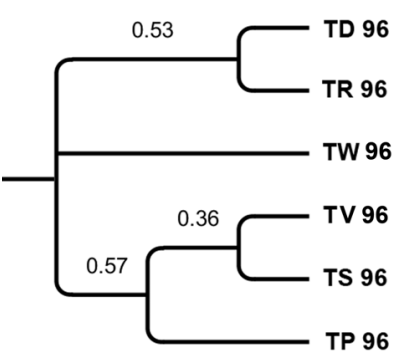

(a)

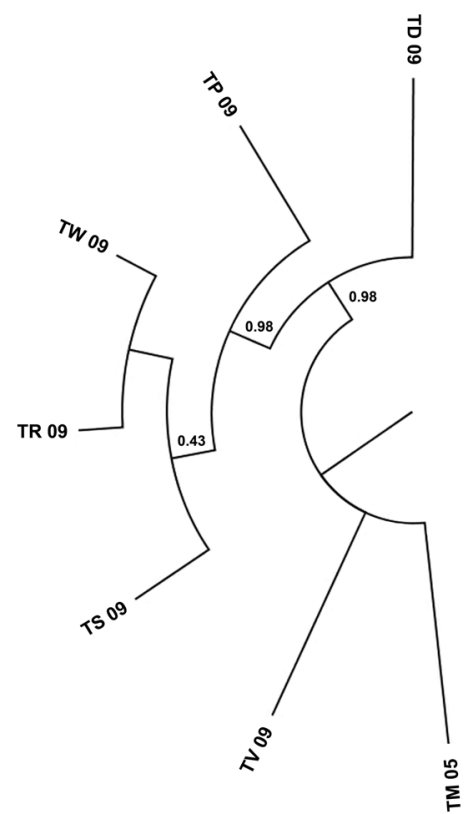

(b)

Fig. 2. Bootstraped neighbor-joining tree based on the $D_{A}$ distances from 22 loci using POPTREE2 software (Takezaki et al. 2010) for sea trout populations sampled in 1996 (a), and 2009 and a hatchery population in 2005 (b).

weakly differentiated due to low homing in Pomeranian populations and long term artificial supplementation (Dębowski and Bartel 1995). The Vistula sea trout populations underwent a bottleneck effect in early 70ties due to the construction of a dam in Włocławek in 1968 (Wass and Bernaś 2016).
Part of genetic unique genotype composition of the native populations in Vistula was lost before the intensive stocking with the Pomeranian sea trout was carried out and cannot be restituted in living papulations. Temporal changes in genetic composition in the studied populations of sea trout in Poland, southern Baltic as identified using SNPs, though low, were observed and concerned mainly the Vistula populations. Values of pairwise $F_{\mathrm{ST}}$ for populations sampled in 2009 were higher suggesting that they are more diverse than those from 1996. There were no significant values in pairwise $F_{\mathrm{ST}}$ in the Pomeranian and Vistula river populations (TV 96 and TD 96). This may be explained by intensive enhancement and the practice of mixing the stocking material carried out in the past. Samples from the Vistula River and Drwęca River collected in 2009 were not significantly differentiated from each other, but were different from each Pomeranian river.

The pairwise comparison between individuals from the same rivers collected at different times (1996 and 2009) revealed that over these 13 years the biggest change was observed for the Vistula River (TV 96 and TV 09) and its tributary the Drwęca River (TD 96 and TD 09) while Pomeranian populations were more stable over time. Pairwise differences of $F_{\text {ST }}$ values between the hatchery population and all the wild populations were statistically significant. A Factorial Correspondence Analysis (FCA) and NJ tree revealed a strong separation of the Aquamar (Miastko) hatchery population. The nearest to it was the Vistula sample collected in 2009. The heterozygosity values inferred from SNPs in this study were at a similar level, around 0.3, in populations sampled in 1996 and 2009.

The hatchery population Aquamar was bred from the winter Vistula sea trout and it did not seem to have the admixture of the Pomeranian sea trout genotype. It accounts for $15-60 \%$ of yearly releases to Vistula in 2000s. The stocking material used for releases in Drwęca River originated from spawners caught in lower river course and sometimes also from specimens electrofished below Włocławek Dam in the Vistula River. Vistula and Drwęca populations seem to become more similar to the hatchery sample from Aquamar over time, which may indicate influence of releases of hatchery fish. Increased divergence between Vistula sea trout and Pomeranian populations can be considered as step towards partial restoration of native population in the Vistula basin. 


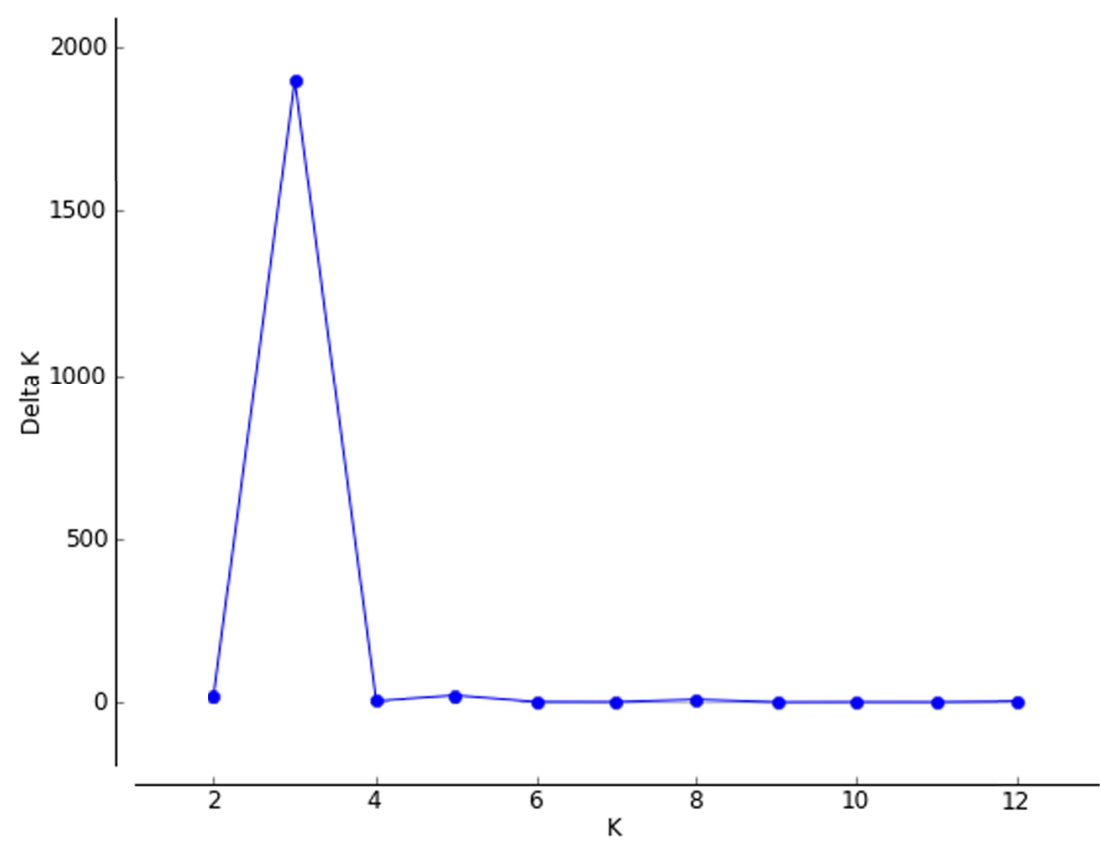

(a)
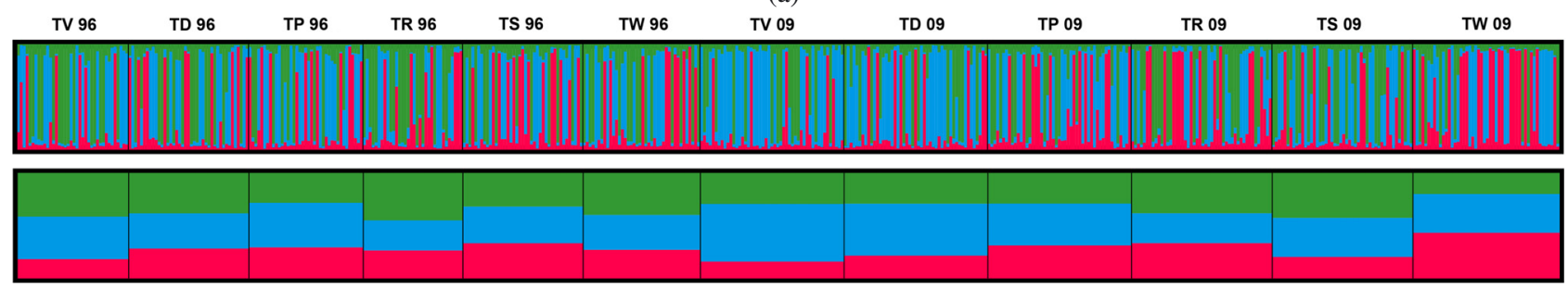

(b)

Fig. 3. (a) $\Delta K$ calculated as $\Delta K=m\left|L^{\prime \prime}(K)\right| / s[L(K)]$ against $K$ values for sea trout populations to identify the optimum number of genetic units. The data generated with STRUCTURE HARVESTER program (Earl and vonHoldt 2012). (b) Proportion of membership of 526 individuals from 12 sea trout populations for $K=3$ calculated by STRUCTURE v.2.3.4 (Pritchard et al. 2000) software and averaged by CLUMPP v.1.1.1 (Jakobsson and Rosenberg 2007) software. Plots were generated by DISTRUCT v.1.1 (Rosenberg 2004) software.

The changes in the genetic structure of sea trout populations from Vistula and Drwęca rivers over the period 19962009 , observed in this study, may be linked to the new strategy of the 'Stocking of Polish marine areas' programme of The Ministry of Agricultural and Rural Development Board. The reduction of the putative Pomeranian genotypes among Vistula populations may also be a result of this stocking strategy, and may lead to a partial recovery of the native Vistula sea trout population. Despite the release of hatchery offspring of individuals chosen for artificial spawning solely into the parental river, specimen selection is not currently based on genetic tests. This leaves a real possibility that spawning individuals can be erroneously selected from 'contaminated' stock, with a pool of ancestors from the Pomeranian populations. Therefore a further genetic monitoring of the source spawners for production of hatchery offspring needs to be developed and performed. However, implementation of genetic monitoring can reduce but not entirely eliminate, negative effects of releases of fish reared in hatcheries (Kallio-Nyberg et al. 2015). Supportive breeding programmes, in which the gametes used for carrying out breeding are collected from spawner fish obtained from the same river area to which the resulting juvenile fish are subsequently released may help to overcome the problem of potential lack of local adaptation but not necessarily a partial loss of allelic richness (Selly et al. 2014). A further process of re-adaptation of the restituted population in Vistula River will be needed over some generations.

\section{Conclusion}

Salmo trutta m. trutta populations in the southern Baltic have been characterized by low degree of genetic differentiation mainly due to admixture prior to the 1990s. The results of the present study prove the occurrence of temporal changes in populations of sea trout in Poland in the period 1996-2009. These changes can be considered to reflect the historic pattern of differentiation between 2 main groups of populations (Vistula and Pomeranian) and, in the studied period, may result from the implementation of a new stocking strategy for the restoration and protection of Vistula sea trout. Clearance of existing and building of new passes for migration of fishes around dams, restitution of river niches appropriate for natural spawning of sea trout could also have influenced the observed changes. In the last 15 years dozens of new fish passes have been constructed on Pomeranian rivers. Also an old fish pass 


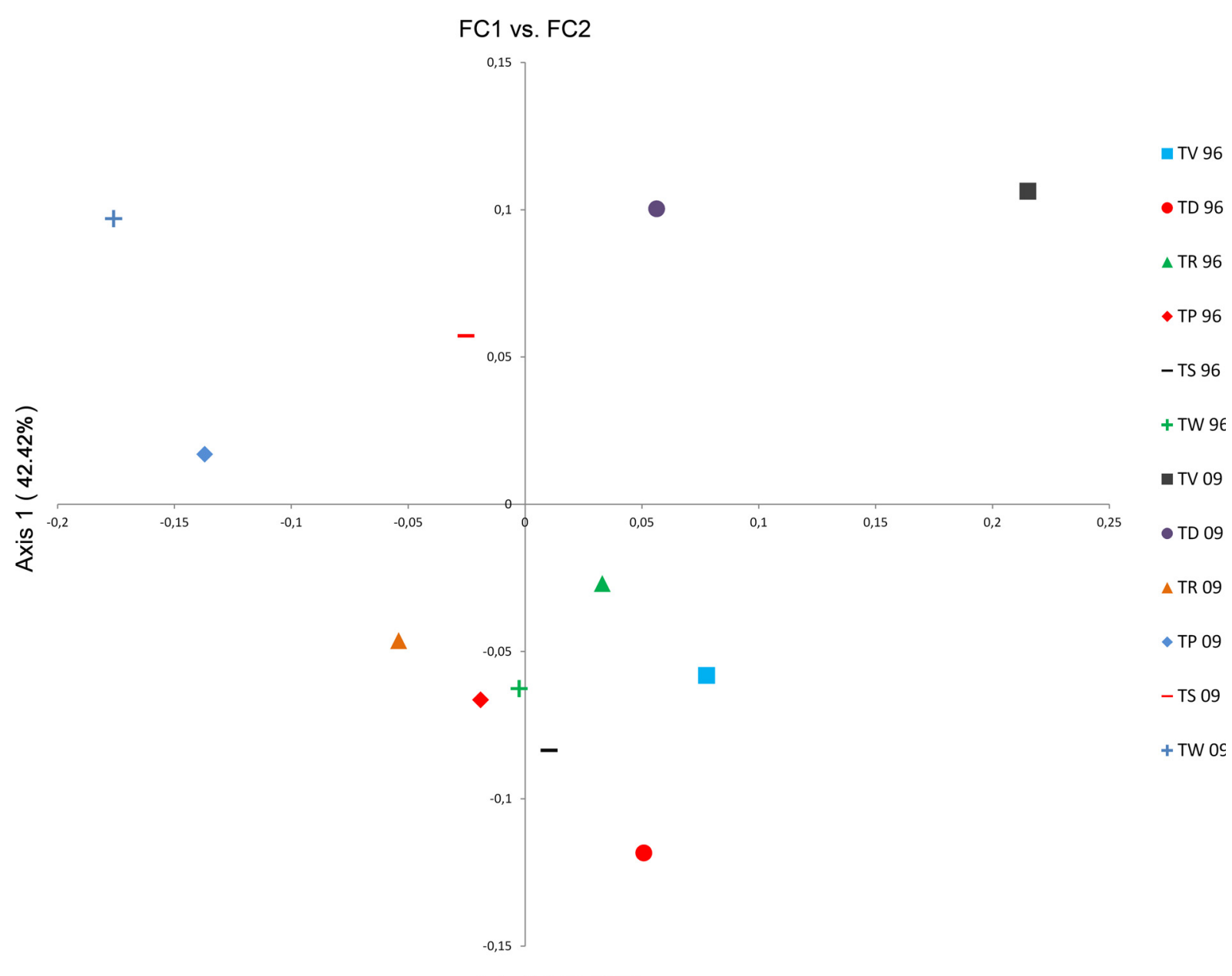

Axis $2(26.82 \%)$

Fig. 4. First two axes of the Factorial Correspondence Analysis (FCA) determined from SNP data for studied trout populations in Poland. Each point represents one sample location. The analysis was performed with Genetix software (Belkhir et al. 2000; Benzécri 1992).

on the Włocławek dam was rebuilt in 2015. All these activities have greatly increased the possibility of sea trout migration. With an increase of natural breeding, artificial enhancement of sea trout populations should be reduced.

Acknowledgements. This study was partially funded by Project No. 397/N-cGRASP/2009/0 of the Ministry of Science and Higher Education in Poland to RW, statutory topic IV.1 in the IO PAS Sopot and S-25 IFI Olsztyn.

\section{References}

An H.S., Shin E.H., Lee J.W., Nam M.M., Myeong J.I., An C.M., 2013, Comparative genetic variability between broodstock and offspring populations of Korean starry flounder used for stock enhancement in a hatchery by using microsatellite DNA analyses. Genet. Mol. Res. 12, 6319-6330.

Araki H., Schmid C., 2010, Is hatchery stocking a help or harm?: Evidence, limitations and future directions in ecological and genetic surveys. Aquaculture 308, S2-S11, Supplement: Genetics in Aquaculture $\mathrm{X}$.
Bartel R., 1988, Trouts in Poland. Pol. Arch. Hydrobiol. 35, 321-339.

Bartel R., 1993, Anadromous fishes in Poland. Bull. Sea Fish. Inst. $128,1-15$.

Baskett M.L., Burgess S.C., Waples R.S., 2013, Assessing strategies to minimize unintended fitness consequences of aquaculture on wild populations. Evol. Appl. 6, 1090-1108.

Beacham T.D., McIntosh B., Wallace C., 2010, A comparison of stock and individual identification for sockeye salmon (Oncorhynchus nerka) in British Columbia provided by microsatellites and single nucleotide polymorphisms. Can. J. Fish. Aquat. Sci. 67, 12741290.

Beaumont A., Boudry P., Hoare K., 2010, Biotechnology and Genetics in Fisheries and Aquaculture, 2nd Edition. Oxford, Wiley-Blackwell, p. 204.

Belkhir K., Borsa P., Chikhi L., Raufaste N., Bonhomme F., 2000, GENETIX 4.05, logiciel sous Windows TM pour la génétique des populations. Laboratoire Génome, Populations, Interactions, CNRS UMR 5171, Université de Montpellier II, Montpellier, France, 1996-2004.

Benzécri J.P., 1992, Correspondence analysis handbook. Statistics: A Series of Text-books and Monographs. New York, Marcel Dekker Inc., p. 688. 
Bernaś R., Burzyński A., Dębowski P., Poćwierz-Kotus A., Wenne R., 2014, Genetic diversity within sea trout population from an intensively stocked southern Baltic river, based on microsatellite DNA analysis. Fisheries Manage. Ecol. 21, 5, 398-409.

Bernaś R., Poćwierz-Kotus A., Dȩbowski P., Wenne R., 2016, The genetic relationship between extirpated and contemporary Atlantic salmon Salmo salar L. lines from the southern Baltic Sea. Genet. Sel. Evol. 48, 29.

Bert T.M., Arnold W.S., McMillen-Jackson A.L., Wilbur A.E., Crawford C., 2011, Natural and Anthropogenic Forces Shape the Population Genetics and Recent Evolutionary History of Eastern United States Bay Scallops (Argopecten irradians). J. Shellfish Res. 30, 583-608.

Blanco Gonzalez E., Umino T., 2009, Fine-scale genetic structure derived from stocking black sea bream, Acanthopagrus schlegelii (Bleeker, 1854), in Hiroshima Bay, Japan. J. Appl. Ichthyol. 25, 407-410.

Blanco Gonzalez E., Aritaki M., Knutsen H., Taniguchi N., 2015, Effects of Large-Scale Releases on the Genetic Structure of Red Sea Bream (Pagrus major, Temminck et Schlegel) Populations in Japan. PLoS One 10, e0125743

Borzęcka I., 2010, Classifying Vistula and Pomeranian sea trout populations using discriminant functions based on selected scale characters. Arch. Pol. Fish. 18, 123-131.

Boscari E., Congiu L., 2014, The need for genetic support in restocking activities andex situconservation programmes: the case of the Adriatic sturgeon (Acipenser naccarii Bonaparte, 1836) in the Ticino River Park. J. Appl. Ichthyol. 30, 1416-1422.

Carlton J.T., 1979, Introduced invertebrates of San Francisco Bay. In: Conomos T.J. (Ed.), San Francisco Bay: The urbanized Estuary. Amer. Assoc. Adv. Sci., Pac. Div. San Francisco, California, pp. 427-444.

Chelenkova P., Petkova R., Yochev S., Vasilev M., Malamov D., Chakarov S., 2012, One Fish, Two Fish, Old Fish, New Fish - Is the Biodiversity of Bulgarian Native Brown Trout (S. trutta fario) Populations at Risk? Biotechnol. Biotechnol. Eq. 26, 2894-2898.

Darden T.L., Sessions F., Denson M.R., 2013, Use of Genetic Microsatellite Markers to Identify Factors Affecting Stocking Success in Striped Bass. Book Series: American Fisheries Society Symposium 80, 395-411.

Dębowski P., Bartel R., 1995, Homing of tagged sea trout (Salmo trutta L.). Smolts released into polish rivers. Arch. Pol. Fish. 3, 107-122.

Drywa A., Poćwierz-Kotus A., Wa̧s A., Dobosz S., Kent M.P., Lien S., Bernaś R., Wenne R., 2013, Genotyping of two populations of Southern Baltic sea trout Salmo trutta m. trutta using an Atlantic salmon derived SNP-array. Mar. Genomics 9, 25-32.

Drywa A., Poćwierz-Kotus A., Dobosz S., Kent M.P., Lien S., Wenne R., 2014. Identification of multiple diagnostic SNP loci for differentiation of three salmonid species using SNP-arrays. Mar. Genomics 15, 5-6.

Earl D.A., vonHoldt B.M., 2012, STRUCTURE HARVESTER: a website and program for visualizing STRUCTURE output and implementing the Evanno method. Conserv. Genet. Resour. 4, 359-361.

Excoffier L., Lischer H.E.L., 2010, Arlequin suite ver 3.5: a new series of programs to perform population genetics analyses under Linux and Windows. Mol. Ecol. Resour. 10, 564-567.

Evanno G., Regnaut S., Goudet J., 2005, Detecting the number of clusters of individuals using the software STRUCTURE: a simulation study. Mol. Ecol. 14, 2611-2620.
Faulks L.K., Gilligan D.M., Beheregaray L.B., 2011, The role of anthropogenic vs. natural in-stream structures in determining connectivity and genetic diversity in an endangered freshwater fish, Macquarie perch (Macquaria australasica). Evol. Appl. 4, 589601.

Filipowicz M., Burzyński A., Ňmietanka B., Wenne R., 2008, Recombination in Mitochondrial DNA of European Mussels Mytilus. J. Mol. Evol. 67, 377-388.

Fraser D.J., Cook A.M., Eddington J.D., Bentzen P., Hutchings J.A., 2008, Mixed evidence for reduced local adaption in wild salmon resulting from interbreeding with escaped farmed salmon: complexities in hybrid fitness. Evol. Appl. 1, 501-512.

Gabriel S., Ziaugra L., Tabbaa D., 2009, SNP genotyping using the Sequenom MassARRAY iPLEX platform. Current Protocols in Human Genetics, Suppl. 60, Unit 2.12.

Glover K.A., Hansen M.M., Lien S., Als T.D., Houheim B., Skaala O., 2010, A comparison of SNP and STR loci for delineating population structure and performing individual genetic assignment. BMC Genet. 11, 2.

Goudet J., 1995, FSTAT Version 1.2: a computer program to calculate F-statistics. J. Hered. 86, 485-486.

Griffiths J.R., Schindler D.E., Seeb L.W., 2013, How stock of origin affects performance of individuals across a meta-ecosystem: an example from sockeye salmon. PLoS One 8, e58584.

Gruenthal K.M., Drawbridge M.A., 2012, Toward responsible stock enhancement: broadcast spawning dynamics and adaptive genetic management in white seabass aquaculture. Evol. Appl. 5, 405417.

Halvorson H., Alexis M., Burgess G., Coimbra J., Le Gal Y., Grealy M., Gutnick D., Höfle M., Smolenicka Z., Walther B., Wenne R. Olafsen J, 2001, Marine Biotechnology: A European Strategy for Marine Biotechnology. European Science Foundation Marine Board Feasibility Study Group Report, ESF Marine Board Position Paper 4, pp 30.

Hansen M.M., Fraser D.J., Meier K., Mensberg K.L.D., 2009, Sixty years of anthropogenic pressure: a spatio-temporal genetic analysis of brown trout populations subject to stocking and population declines. Mol. Ecol. 18, 2549-2562.

Hansen M.M., Ruzzante D.E., Nielsen E.E., Bekkevold D., Mensberg K.L.D., 2002, Long-term effective population sizes, temporal stability of genetic composition and potential for local adaptation in anadromous brown trout (Salmo trutta) populations. Mol. Ecol. 11, 2523-2535.

Hansen M.M., Limborg M.T., Ferchaud A.L., Pujolar J.M., 2014, The effects of Medieval dams on genetic divergence and demographic history in brown trout populations. BMC Evol. Biol. 14, 122.

Hasegawa K., Maekawa K., 2008, Different longitudinal distribution patterns of native white-spotted charr and non-native brown trout in Monbetsu stream, Hokkaido, northern Japan. Ecol. Freshwat. Fish 17, 189-192.

HELCOM, 2011, Salmon and Sea Trout Populations and Rivers in the Baltic Sea. HELCOM assessment of salmon (Salmo salar) and sea trout (Salmo trutta) populations and habitats in rivers to the Baltic Sea. Baltic Sea Environment Proceedings No. 126A, p. 82.

Horváth Á., Hoitsy G., Kovács, B., Kánainé Sipos D., Õsz, Á., Bogataj, K., Urbányi, B, 2013, The effect of domestication on a brown trout (Salmo trutta m. fario) broodstock in Hungary. Aquacult. Int. 22, 5-11.

ICES, 2013, Report of the Baltic Salmon and Trout Assessment Working Group (WGBAST), 3-12 April 2013, Tallinn, Estonia. ICES CM 2013/ACOM: 08, p. 334. 
Jager H.I., Chandler J.A., Lepla K.B., Van Winkle W., 2001, A theoretical study of river fragmentation by dams and its effects on white sturgeon populations. Environ. Biol. Fishes 60, 347-361.

Jakobsson M., Rosenberg N.A., 2007, CLUMPP: a cluster matching and permutation program for dealing with label switching and multimodality in analysis of population structure. Bioinformatics 23, 1801-1806.

Jensen L.F., Hansen M.M., Carlsson J., Loeschcke V., Mansberg K.L.D., 2005, Spatial and temporal genetic differentiation and effective population size of brown trout (Salmo trutta, L.) in small Danish rivers. Conserv. Genet. 6, 615-621.

Kalinowski S.T., Manlove K.R., Taper, M.L., 2007, ONCOR: A Computer Program for Genetic Stock Identification. Department of Ecology. Montana State University, Bozeman, MT. http:// www.montana.edu/kalinowski/Software/ONCOR.htm.

Kallio-Nyberg I., Romakkaniemi A., Jokikokko E., Saloniemi I., Jutila E., 2015, Differences between wild and reared Salmo salar stocks of two northern Baltic Sea rivers. Fish. Res. 165, 85-95.

Kijewski T., Wijsman J.W.M., Hummel H, Wenne R. 2009 Genetic composition of cultured and wild mussels Mytilus from Netherlands and transfers from Ireland and Great Britain. Aquaculture 287, 292-296

Klemetsen A., Amundsen P.A., Dempson J.B., Jonsson B., Jonsson N., O'Connell M.F., Mortensen E., 2003, Atlantic salmon Salmo salar L., brown trout Salmo trutta L. and Arctic charr Salvelinus alpinus (L.): a review of aspects of their life histories. Ecol. Freshwat. Fish 12, 1-59.

Kohout J., Šedivá A., Apostolou A., Stefanov T., Maræ S., Gaffarðlu M., Elechta V., 2013, Genetic diversity and phylogenetic origin of brown trout Salmo trutta populations in eastern Balkans. Biologia 68, 1229-1237.

Koljonen M.L., Pella J.J., Masuda M., 2005, Classical individual assignments versus mixture modeling to estimate stock proportions in Atlantic salmon (Salmo salar) catches from DNA microsatellite data. Can. J. Fish. Aquat. Sci. 62, 2143-2158.

Koljonen M.L., Gross R., Koskiniemi J, 2014, Wild Estonian and Russian sea trout (Salmo trutta) in Finnish coastal sea trout catches: results of genetic mixed-stock analysis. Hereditas 151, 177-195.

Lallias D. Boudry P. Batista F.M. Beaumont A. King J.W., Turner J.R. Lapègue S., 2015, Invasion genetics of the Pacific oyster Crassostrea gigas in the British Isles inferred from microsatellite and mitochondrial markers. Biol. Invasions 17, 2581-2595.

Laikre L., Schwartz M.K., Waples R.S., Ryman N. and The GeM Working Group, 2010, Compromising genetic diversity in the wild: unmonitored large-scale release of plants and animals. Trends Ecol. Evol 25, 520-529.

Lamaze F.C., Sauvage C., Marie A., Garant D., Bernatchez L., 2012, Dynamics of introgressive hybridization assessed by SNP population genomics of coding genes in stocked brook charr (Salvelinus fontinalis). Mol. Ecol. 21, 2877-2895.

Liu Y., Diserud O.H., Hindar K., Skonhoft A., 2013, An ecologicaleconomic model on the effects of interactions between escaped farmed and wild salmon (Salmo salar). Fish Fish. 14, 158-173.

Łuczyński M., Bartel R., Vuorinen J.A., Domagała J., ŕółkiewicz L., Brzuzan, P., 2000, Biochemical genetic characteristics of Polish sea trout (Salmo trutta trutta L.) populations. Pol. Arch. Hydrobiol. 47, 21-28.

Madeira M.J., Gomez-Moliner B.J., Machordom A., 2005, Genetic introgression on freshwater fish populations caused by restocking programmes Biol. Invasions 7, 117-125.
Marshall S.H., Ramirez R., Labra A., Carmona M., Munoz C., 2014, Bona fide evidence for natural vertical transmission of infectious salmon anemia virus in freshwater brood stocks of farmed Atlantic salmon (Salmo salar) in Southern Chile. J. Virol 88, 6012-6018

McQuaid C.D., Porri F., Nicastro K.R., Zardi G.I., 2015, Simple, scale-dependent patterns emerge from very complex effects-an example from the intertidal mussel Mytilus galloprovincialis and Perna perna. Oceanogr. Mar. Biol. 53, 127-156.

Meehan W.B., Carlton J., Wenne R., 1989, Genetic affinities of the bivalve Macoma balthica from the Pacific coast of North America: evidence for recent introduction and historical distribution. Mar. Biol. 102, 235-241.

Meldgaard T., Nielsen E.E., Loeschcke V., 2003, Fragmentation by weirs in a riverine system: A study of genetic variation in time and space among populations of European grayling (Thymallus thymallus) in a Danish river system. Conserv. Genet. 4, 735-747.

Milano I., Babbucci M., Cariani A., Atanassova M., Bekkevold D., Carvalho G.R., Espineira M., Fiorentino F.,Garofalo G., Geffen A.J., Hansen J.H., Helyar S.J., Nielsen E.E., Ogden R., Patarnello T., Stagioni M., FishPopTrace Consortium, Tinti F., Bargelloni L., 2014, Outlier SNP markers reveal fine-scale genetic structuring across European hake populations (Merluccius merluccius). Mol. Ecol. 23, 118-135

Miller P.A., Elliott N.G., Koutoulis A., Kube P.D., Vaillancourt R.E., 2012, Genetic Diversity of Cultured, Naturalized, and Native Pacific Oysters, Crassostrea gigas, Determined from Multiplexed Microsatellite Markers. J. Shellfish Res. 31, 611-617.

Milot E., Perrier C., Papillon L., Dodson J.J., Bernatchez L., 2013, Reduced fitness of Atlantic salmon released in the wild after one generation of captive breeding. Evol. Appl. 6, 472-485.

Mineur F., Provan J., Arnott G., 2014, Phylogeographical analyses of shellfish viruses: inferring a geographical origin for ostreid herpesviruses OsHV-1 (Malacoherpesviridae). Mar. Biol. 162, 181192.

Morin P.A., Luikart G., Wayne R.K., The SNP Workshop Group, 2004, SNPs in ecology, evolution and conservation. Trends Ecol. Evol. 19, 208-216.

Morita K., Yamamoto S., 2002, Effects of habitat fragmentation by damming on the persistence of stream-dwelling charr populations. Conserv Biol. 16, 1318-1323.

Murray A.G., 2013, Epidemiology of the spread of viral diseases under aquaculture. Curr. Opin. Virol. 3, 74-78.

Naish K.A., Seamons T.R., Dauer M.B., Hauser L., Quinn T.P., 2013, Relationship between effective population size, inbreeding and adult fitness-related traits in a steelhead (Oncorhynchus mykiss) population released in the wild. Mol. Ecol. 22, 1295-1309.

Nakajima K., Kitada S., Habara Y., Sano S., Yokoyama E., Sugaya T., Iwamoto A., Kishino H., Hamasaki K., Taylor E., 2014, Genetic effects of marine stock enhancement: a case study based on the highly piscivorous Japanese Spanish mackerel. Can. J. Fish. Aquat. Sci. 71, 301-314.

Nei M., 1978, Estimation of average heterozygosity and genetic distance from a small number of individuals. Genetics 89, 583-590.

Nei M., 1987, Molecular Evolutionary Genetics, New York, Columbia University Press, p. 512.

Ostergaard S., Hansen M.M., Loeschcke V., Nielsen W.E., 2003, Long-term temporal changes of genetic composition in brown trout (Salmo trutta L.) populations inhabiting an unstable environment. Mol. Ecol. 12, 3123-3135. 
Ozerov M., Vasemagi A., Wennevik V., Diaz-Fernandez R., Kent M., Gilbey J., Prusov S., Niemela E., Vaha J.P., 2013, Finding markers that make a difference: DNA pooling and SNP-arrays identify population informative markers for genetic stock identification. PloS ONE 8, e82434.

Paris J.R., King R.A., Stevens J.R., 2015, Human mining activity across the ages determines the genetic structure of modern brown trout (Salmo trutta L.) populations. Evol. Appl. 8, 573-585.

Pedersen S., Heinimaa P., Pakarinen T. (Eds.), 2012, Workshop on Baltic Sea Trout, Helsinki, Finland, 11-13 October 2011 DTU Aqua Report No 248-2012. National Institute of Aquatic Resources, Technical University of Denmark, p. 95.

Perrier C., Guyomard R., Bagliniere J.L., Nikolic N., Evanno G., 2013, Changes in the genetic structure of Atlantic salmon populations over four decades reveal substantial impacts of stocking and potential resiliency. Ecol Evol 3, 2334-2349.

Poćwierz-Kotus A., Wenne R., 2010, Properties of mobile elements of genomes and their application in biotechnology. Environ. Biotech. 6, 24-36.

Poćwierz-Kotus A., Burzyński A, Wenne R., 2007, Family of Tc1like elements from fish genomes and horizontal transfer. Gene 390, 243-251.

Poćwierz-Kotus A., Burzyński A, Wenne R., 2010, Identification of a Tc1-like transposon integration site in the genome of the flounder (Platichthys flesus): a novel use of an inverse PCR method. Mar. Genomics 3, 45-50.

Poćwierz-Kotus A., Bernaś R., Dębowski P., Kent M.P., Lien. S., Kesler M., Titov S., Leliuna E., Jespersen H., Drywa A., Wenne R., 2014, Genetic differentiation of southeast Baltic populations of sea trout inferred from single nucleotide polymorphisms. Anim. Genet. 45, 96-104.

Poćwierz-Kotus A., Bernaś R., Kent M.P., Lien S., Leliuna E., Dębowski P., Wenne R., 2015a Restitution and genetic differentiation of salmon populations in the southern Baltic genotyped with the Atlantic salmon 7K SNP array. Gen Sel Evol. $47,39$.

Poćwierz-Kotus A., Kijewska A., Petereit C., Bernaś R., Więcaszek B., Arnyasi M., Lien S., Kent M.P.,Wenne R., 2015b, Genetic differentiation of brackish water populations of cod Gadus morhua in the southern Baltic, inferred from genotyping using SNParrays. Mar. Genomics 19, 17-22.

Poteaux C., Berrebi P., 1997, Intégrité génomique et repeuplements chez la truite commune du versant méditerranéen. Bull. Fr. Pêche Piscic. 344-345, 309-322.

Pritchard J.K., Stephens M., Donnelly P., 2000, Inference of population structure using multilocus genotype data. Genetics $155,945-$ 959.

Pukk L., Kuparinen A., Järv L., Gross R., Vasemägi A., 2013, Genetic and life-history changes associated with fisheries-induced population collapse. Evol. Appl. 6, 749-760.

Pustovrh G., Sušnik Bajec S., Snoj, A., 2012, A set of SNPs for Salmo trutta and its application in supplementary breeding programs. Aquaculture 370-371, 102-108.

Rice W.R., 1989, Analyzing tables of statistical tests. Evolution 43, 223-225.

Salminen M., Koljonen M.L., Säisä M., Ruuhijärvi J., 2012, Genetic effects of supportive stockings on native pikeperch populations in boreal lakes - three cases, three different outcomes. Hereditas $149,1-15$.

Satake A., Araki H., 2011, Stocking of captive-bred fish can cause long-term population decline and gene pool replacement: predictions from a population dynamics model incorporating densitydependent mortality. Theor. Ecol. 5, 283-296.
Seeb J.E., Carvalho G., Hauser L., Naish K., Roberst S., Seeb L.W., 2011, Single-nucleotide polymorphism (SNP) discovery and applications of SNP genotyping in nonmodel organisms. Mol. Ecol. Resour. 11, S1-S8.

Selly S.L.C., Hickey J., Stevens J.R., 2014, A tale of two hatcheries: Assessing bias in the hatchery process for Atlantic salmon (Salmo salar L.). Aquaculture 434, 254-263.

Sušnik Bajec S., Pustovrh G., Jesenšek D., Snoj A., 2015, Population genetic SNP analysis of marble and brown trout in a hybridization zone of the Adriatic watershed in Slovenia. Biol. Conserv. 184, 239-250.

Takezaki N., Nei M., Tamura K., 2010, POPTREE2: Software for Constructing Population Trees from Allele Frequency Data and Computing Other Population Statistics with Windows Interface. Mol. Biol. Evol. 27, 747-752.

Thaulow J., Borgstrøm R., Heun M., 2012, Brown trout population structure highly affected by multiple stocking and river diversion in a high mountain national park. Conserv. Genet. 14, 145-158.

Thaulow J., Borgstrøm R., Heun M., 2014, Genetic persistence of an initially introduced brown trout (Salmo trutta L.) population despite restocking of foreign conspecifics. Ecol. Freshwater Fish 23, 485-497.

Turek K.C., Pegg M.A., Pope K.L., Schainost S., 2016, Potential population and assemblage influences of non-native trout on native nongame fish in Nebraska headwater streams. Ecol. Freshwater Fish 25, 99-108.

Utter F., Aebersold P., Winans G., 1987, Interpreting genetic variation detected by electrophoresis. In: Ryman N., Utter F. (Eds.), Population Genetics and Fishery Management, Sea Grant Program/University of Washington Press, Seattle and London, pp. 21-46.

Valiquette E., Perrier C., Thibault I., Bernatchez L., 2014, Loss of genetic integrity in wild lake trout populations following stocking: insights from an exhaustive study of 72 lakes from Quebec, Canada Evol. Appl. 7, 625-644.

Vigilano P.H., Fabian M., Aquaculture M., 2007, Salmonid introductions in Patagonia: A mixed blessing. Ecological and genetic implications of aquaculture activities. Reviews: Methods and Technologies in Fish Biology and Fisheries, 6, 315-331.

Ward R.D., 2006, The importance of identifying spatial population structure in restocking and stock enhancement programmes. Fish. Res. 80, 9-18.

Wa̧s A., Bartel R., Wenne R., 2004, Molecular characteristics of sea trout populations in Poland: implications for stocking. Arch. Pol. Fish. 12, 253-266.

Wạs A., Bernaś R., 2016, Long-term and seasonal genetic differentiation in wild and enhanced stocks of sea trout (Salmo trutta $\mathrm{m}$. trutta L.) from the Vistula River, in the southern Baltic - management implications. Fish. Res. 175, 57-65.

Wạs A. Wenne R, 1998, Microsatellites as molecular markers are useful tools in fishery and aquaculture. Rap. Mor. Inst. Ryb. 1997, $37-47$.

Wass A. Wenne R., 2002, Genetic differentiation in hatchery and wild sea trout (Salmo trutta) in the Southern Baltic at microsatellite loci. Aquaculture 204, 493-506.

Wa̧s A., Wenne R., 2003 Microsatellite DNA polymorphism in intensely enhanced populations of sea trout (Salmo trutta) in the Southern Baltic. Mar Biotechnol. 5, 234-243.

Weir B.S., 1996 Genetic Data Analysis II: Methods for Discrete Population Genetic Data, Sinauer Press, Sunderland, Massachusetts. 
Weir B.S., Cockerham C.C., 1984 Estimating F-statistics for the analysis of population structure. Evolution 38, 1358-1370.

Wenne R., 1992, Enzyme electrophoretic variation of the coot clam (Mulinia lateralis, Bivalvia) along the Atlantic coast of the USA. Genetica Polonica 33, 131-139.

Wenne R., Łuczyński M., Bartel R., 2000, Evaluation of possibilities of distinguishing sea trout populations in Poland using genetic methods. Stud. Mat. MIR Gdynia Ser. B 71, 11-19.

Wenne R., Boudry P., Hemmer-Hansen J., Lubieniecki K.P., Was A., Kause A. 2007, What role for genomics in fisheries management and aquaculture? Aquat. Living Resour 20, 241-255.

Wenne R., Handschuh L., Poćwierz-Kotus A., Urbaniak R, Formanowicz P., Całkiewicz J., Brzozowska K., Figlerowicz M., Wçgrzyn G., Wróbel B., 2011, The application of microarray technology to the identification of Tc1-like element sequences in fish genomes. Mar. Biol Res 7, 466-477.
Włodarczyk E., Wenne R., 2001 Mitochondrial DNA variation in sea trout from coastal rivers in the southern Baltic region. ICES J. Mar. Sci. 58, 230-237.

Włodarczyk, E., Butowska A., Wenne R., 1999, A study of polymorphism within growth hormon gene 2 in sea trout from Polish coastal rivers using heteroduplex analysis. Bull. Sea Res. Inst. 3, 57-61.

Woźnicki P., Jankun M. Kucharczyk, D. Boron, A., Łuczyński M., 1999, Cytogenetic characterization of sea trout (Salmo trutta) from Poland. Copeia 2, 501-505.

Young K.A., Dunham J.B., Stephenson J.F., Terreau A., Thailly A.F., Gajardo G., Garcia de Leaniz C., 2010, A trial of two trouts: comparing the impacts of rainbow and brown trout on a native galaxiid. Anim. Conserv 13, 399-410.

Żarnecki S., 1963, Występowanie populacji sezonowych u łososia atlantyckiego (Salmo salar L.) oraz u troci (Salmo trutta L.) w rzece Wiśle. Acta Hydrobiol 5, 255-294. 